\title{
Synthesis, Characterization and Cytotoxic Studies of New Thiazolidinones
}

\author{
Shafia Mir ${ }^{1}$, Masrat Jan ${ }^{1}$, Praveen Kumar ${ }^{1}$ and Ayaz Mahmood Dar ${ }^{2 *}$ \\ ${ }^{1}$ Department of Chemistry, OPJS University, Rajasthan, India \\ ${ }^{2}$ Department of Chemistry GDC Kulgam, University of Kashmir, Jammu and Kashmir, India
}

Submission: September 29, 2018 Published: October 09, 2018

"Corresponding author: Ayaz Mahmood Dar, Department of Chemistry GDC Kulgam, University of Kashmir, Jammu and Kashmir, India, Tel: +91 9286990247; Email: ayazchem09@gmail.com

\begin{abstract}
A new series of substituted aromatic thiazolidinones [1-4]were synthesized by the reaction of acetophenone and its derivatives [5-8]with hydrazine hydrate and merceptoacetic acid in absolute ethanol in one pot manner. The striking feature of this reaction is the formation of hydrazone in situ which in turn undergoes the cyclization with mercepto acetic acid, leading to the formation of new thiazolidinones. Thus, the thiazolidinone ring closes at carbonyl carbon, by the attack of sulfur of mercaptoacetic acid moiety, preferentially from the front ( $\beta$, axial) so that the nitrogen has an equatorial orientation ( $\alpha$, equatorial) to avoid steric repulsion, giving minimum steric hindrance. The new compounds were characterized by spectral (IR, ${ }^{1} \mathrm{H}$ NMR, ${ }^{13} \mathrm{C}$ NMR, MS) and analytical methods. The new compounds were screened for cytotoxicity (MTT assay) as well as genotoxicity (Comet assay) studies against different cancer cell lines, during which the new compounds depicted potential anticancer behaviour.
\end{abstract}

\section{Introduction}

Heterocycles have been accredited with a great amount of attention over the years by medicinal chemists for drug discovery. The interesting structural and stereochemical features of the heterocyclic compounds provide additional fascination to the researchers and thereby alterations in the skeleton have been envisaged to discover new chemical entities with a potential to afford some promising drugs of the future. The incorporation of a heterocyclic ring like thiazolidinone, thiazole or a heteroatom in the heterocyclic backbone affects the chemical properties of a heterocycle and often results in useful alterations in its biological activities [1]. Therefore, researchers are on a continuous pursuit to design and produce better heterocyclic derivatives, by following natural models. The discovery of several biologically active heterocyclic derivatives with their wide applications in therapy has also brought about an interesting interest [1]. Thiazolidinones which is an important class of heterocyclic compounds are classified as doubly unsaturated five membered heterocyclic compounds contain one nitrogen, one sulphur and three carbon atoms including a carbonyl group. Thiazolidinones have been reported to show versatile pharmacological activities. They have been reported as COX-1 inhibitor [2], anti-inflammatory [3], antiproliferative [4,5], antihistaminic [6], anti-HIV [7,8], hypnotic [9], anaesthetic [10], antifungal [11], anthelmintic [12] and antiviral [13] agents as well as CNS [14] stimulants. 4-thiazolidinones and their derivatives [15] exhibit unusually high activity against Mycobacterium tuberculosis. Recently, a number of 4-thiazolidinones derivatives found to exhibit highly potent and selective anti-Platelet activating factor activity both in vitro and in vivo [16]. 2-Arylimino-4-thiazolidinone derivatives have also showed antibacterial $[17,18]$, antifungal [19] and anticonvulsant activities $[20,21]$. Keeping in view the applications of heterocycles and in continuation of previous work [22] we herein report the synthesis and anticancer studies of aromatic appended thiazolidinone derivatives.

\section{Experimental}

\section{Chemistry}

All the melting points were determined in degrees Celsius on a Kofler apparatus and are uncorrected. The IR spectra were recorded on KBr pellets with Perkin Elmer RXI Spectrophotometer and values are given in $\mathrm{cm}^{-1} \cdot{ }^{1} \mathrm{H}$ and ${ }^{13} \mathrm{C}$ NMR spectra were run in $\mathrm{CDCl}_{3}$ on a JEOL Eclipse (400 MHz) instrument with TMS as internal standard and values are given in ppm $(\delta)$. Mass spectra were recorded on a JEOL SX 102/DA-6000 Mass Spectrometer. Thin layer chromatography (TLC) plates were coated with silica gel $G$ and exposed to iodine vapors to check the homogeneity as well as the progress of reaction. Petroleum ether refers to a fraction of boiling point $60-80^{\circ} \mathrm{C}$. Sodium sulfate (anhydrous) was used as a drying agent. All the chemicals were purchased from Merck India and were used after distillation. 
General method of synthesis of 3-amino-2-methyl-2-phenyl thiazolidinone [5-8]

Acetophenone and its derivatives [5-8] (1 mmol), hydrazine hydrate $(1 \mathrm{mmol})$, mercaptoacetic acid $(3.0 \mathrm{mmol})$ and few drops of conc. $\mathrm{HCl}$ were reflux in ethanol for $5 \mathrm{~h}$. The progress and completion of the reaction was monitored by TLC. After completion of reaction, the excess solvent was reduced to three fourths of the original volume under reduced pressure. The reaction mixture was then taken in ether, washed with water and dried over anhydrous sodium sulfate. Evaporation of solvents and crystallization from methanol afforded the corresponding thiazolidinones [5-8].

\section{3-Amino-2-methyl-2-phenyl thiazolidin-4-one [5]}

Yield (68\%); Mp: $149{ }^{\circ} \mathrm{C}$; Anal. Calcd for $\mathrm{C}_{10} \mathrm{H}_{12} \mathrm{~N}_{2} \mathrm{OS}$ : C, 57.67; H, 5.81; N, 13.45; found; C, 57.57, H, 5.71, N, 13.34; IR (KBr) $v \mathrm{~cm}^{-1}$ 3215 (NH2), 1645 (C=0), 1229 (C-N), 647 (C-S); 1H NMR (CDCl $500 \mathrm{MHz}) \delta 7.35\left(\mathrm{~s},{ }^{1} \mathrm{H}, \mathrm{NH}_{2}\right.$, exchangeable with $\left.\mathrm{D}_{2} \mathrm{O}\right), \delta 4.2(\mathrm{~s}, 3 \mathrm{H}$, $\mathrm{CH}_{3}$ ), 3.36 (s, $2 \mathrm{H}, \mathrm{CH}_{2}$ ), 6.4-6.9 (m, 5H, aromatic); 13C NMR ( $\mathrm{CDCl}_{3}$, $125 \mathrm{MHz}) \delta 173(\mathrm{C}=0), 121-130$ (6C, aromatic), $48(\mathrm{C}-\mathrm{N}), 38\left(\mathrm{CH}_{2}\right)$. MS (EI): (m/z) 208 [M+.].

\section{3-Amino-2-methyl-2-(3'-hydroxyl) phenyl thiazolidin-4-one} [6]

Yield (71\%); Mp: $154^{\circ} \mathrm{C}$; Anal. Calcd for $\mathrm{C}_{10} \mathrm{H}_{12} \mathrm{~N}_{2} \mathrm{O}_{2} \mathrm{~S}$ : C, 57.67; $\mathrm{H}, 5.81$; N, 13.45; found; C, 57.57, H, 5.71, N, 13.34; IR (KBr) v cm${ }^{-1}$ $3358(\mathrm{OH}), 3218\left(\mathrm{NH}_{2}\right), 1678(\mathrm{C}=0), 1234(\mathrm{C}-\mathrm{N}), 1080$ (C-O), 680 $(\mathrm{C}-\mathrm{S}) ;{ }^{1} \mathrm{H}$ NMR $\left(\mathrm{CDCl}_{3}, 500 \mathrm{MHz}\right) \delta 8.2(\mathrm{~s}, 1 \mathrm{H}, \mathrm{OH}$, exchangeable with $\left.\mathrm{D}_{2} \mathrm{O}\right), \delta 7.5\left(\mathrm{~s}, 1 \mathrm{H}, \mathrm{NH}_{2}\right.$, exchangeable with $\left.\mathrm{D}_{2} \mathrm{O}\right), \delta 4.2(\mathrm{~s}, 3 \mathrm{H}$, $\mathrm{CH}_{3}$ ), 3.38 (s, $\left.2 \mathrm{H}, \mathrm{CH}_{2}\right), 6.4-6.6$ (m, $4 \mathrm{H}$, aromatic); ${ }^{13} \mathrm{C} \mathrm{NMR}\left(\mathrm{CDCl}_{3^{\prime}}\right.$ $125 \mathrm{MHz}) \delta 176(\mathrm{C}=0), 121-134\left(6 \mathrm{C}\right.$, aromatic), $49(\mathrm{C}-\mathrm{N}), 40\left(\mathrm{CH}_{2}\right)$; MS (EI): (m/z) 224 [M+.].

\section{3-Amino-2-methyl-2-(4'-hydroxyl) phenyl thiazolidin-4-one} [7]

Yield (71\%); Mp: $155{ }^{\circ} \mathrm{C}$; Anal. Calcd for $\mathrm{C}_{10} \mathrm{H}_{12} \mathrm{~N}_{2} \mathrm{O}_{2} \mathrm{~S}$ : C, 57.67; $\mathrm{H}, 5.81$; N, 13.45; found; C, 57.57, H, 5.71, N, 13.34; IR (KBr) v cm ${ }^{-1}$ $3336(\mathrm{OH}), 3220\left(\mathrm{NH}_{2}\right), 1671(\mathrm{C}=0), 1229$ (C-N), 1080 (C-O), 667 (C-S); $1 \mathrm{H} \mathrm{NMR}\left(\mathrm{CDCl}_{3}, 500 \mathrm{MHz}\right) \delta 8.0(\mathrm{~s}, 1 \mathrm{H}, \mathrm{OH}$, exchangeable with $\left.\mathrm{D}_{2} \mathrm{O}\right), \delta 7.3\left(\mathrm{~s}, 1 \mathrm{H}, \mathrm{NH} 2\right.$, exchangeable with $\left.\mathrm{D}_{2} \mathrm{O}\right), \delta 4.2(\mathrm{~s}, 3 \mathrm{H}$,

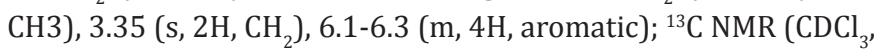
$125 \mathrm{MHz}) \delta 172(\mathrm{C}=0), 121-129$ (6C, aromatic), $47(\mathrm{C}-\mathrm{N}), 44\left(\mathrm{CH}_{2}\right)$; MS (EI): (m/z) 224 [M+.].

\section{3-Amino-2-methyl-2-(2', 4'-dihydroxyl) phenyl thiazolidinone [8]}

Yield (71\%); Mp: $160{ }^{\circ} \mathrm{C}$; Anal. Calcd for $\mathrm{C}_{10} \mathrm{H}_{12} \mathrm{~N}_{2} \mathrm{O}_{3} \mathrm{~S}$ : C, 49.99; H, 5.03; N, 11.66; found; C, 49.80, H, 5.00, N, 11.47; IR (KBr) v cm $\mathrm{cm}^{-1}$ 3321, 3318 (OH), 3236 (NH2), 1679 (C=0), 1229 (C-N), 1080 (C0), 667 (C-S); ${ }^{1} \mathrm{H}$ NMR ( $\left.\mathrm{CDCl}_{3}, 500 \mathrm{MHz}\right) \delta 8.2,8.0(\mathrm{~s}, 1 \mathrm{H}, 2 \times \mathrm{OH}$, exchangeable with $\left.\mathrm{D}_{2} \mathrm{O}\right), \delta 7.5\left(\mathrm{~s}, 1 \mathrm{H}, \mathrm{NH}_{2}\right.$, exchangeable with $\mathrm{D}_{2} \mathrm{O}$ ), $\delta 4.2\left(\mathrm{~s}, 3 \mathrm{H}, \mathrm{CH}_{3}\right), 3.44\left(\mathrm{~s}, 2 \mathrm{H}, \mathrm{CH}_{2}\right), 6.2-6.4\left(\mathrm{~m}, 3 \mathrm{H}\right.$, aromatic); ${ }^{13} \mathrm{C}$ NMR $\left(\mathrm{CDCl}_{3}, 125 \mathrm{MHz}\right) \delta 174(\mathrm{C}=0), 121-131$ (6C, aromatic), 50 (C-N), $43\left(\mathrm{CH}_{2}\right)$; MS (EI): (m/z) 240 [M+.].

\section{Anticancer activity}

Cell Lines and Culture Conditions: Human cancer cell lines used for the study were A545 (lung carcinoma cells)/ATCC (CRL2579), MCF7 (breast cancer cells)/ATCC (HTB-22), HeLa (cervical cancer cells)/ATCC (CCL-2), HL-60 (Leukaemia cells)/ATCC (CCL240), SW480 (colon adenocarcinoma cells)/ATCC (CCL-228), HepG2 (hepatic carcinoma cells)/ATCC (CRL-8065), HT-29 (colon cancer cells)/ATCC (HTB-38), DU145 (pancreatic cancer cells)/ ATCC (HTB-81) and A549 (lung carcinoma cells)/ATCC (CCL-185) were obtained from National Cancer Institute (NCI), biological testing branch, Federick Research and Development Centre, USA. SW480, A549, A545, HL-60, HT29, DU145 and HepG2 cells were grown in RPMI-1640 182 supplemented with 10\% fetal bovine serum (FBS), $10 \mathrm{U}$ penicillin and $100 \mu \mathrm{g} / \mathrm{mL}$ streptomycin at $37^{\circ} \mathrm{C}$ with $5 \% \mathrm{CO}_{2}$ in a humidified atmosphere. HeLa and MCF7 cells were grown in Dulbecco's modified Eagle's medium (DMEM) 183 supplanted with FCS and antibiotics as described above for RPMI 1640. The non-cancer cells i.e. 184B5 and MCF10A breast cells were maintained in mammary epithelial basal medium supplemented with an MEGM mammary epithelial singlequot kit (Cambrex). NL-20 (normal lung cells), HPC (normal pulp cells), HPLF (periodontal ligament fibroblasts) were grown at $37^{\circ} \mathrm{C}$ with $5 \% \mathrm{CO}_{2}, 95 \%$ air under the humidified conditions. Fresh medium was given every second day and on the day before the experiments were done. Cells were passaged at preconfluent densities, using a solution containing $0.05 \%$ trypsin and $0.5 \mathrm{mM}$ EDTA.

Cell Viability Assay (MTT): The in vitro cytotoxicity was measured using the MTT assay. The assay was carried out according to known protocol [23]. Exponentially growing cells were harvested and plated in 96-well plates at a concentration of $1 \times 10^{4}$ cells/well. After $24 \mathrm{~h}$ incubation at $37{ }^{\circ} \mathrm{C}$ under a humidified $5 \%$ $\mathrm{CO}_{2}$ to allow cell attachment, the cells in the wells were respectively treated with target compounds at various concentrations for 48h. The concentration of DMSO was always kept below $1.25 \%$, which was found to be non-toxic to the cells. A solution of 3-(4, 5-dimethylthiazo1-2-y1)-2, 5-diphenyltetrazolium bromide (MTT), was prepared at $5 \mathrm{mg} / \mathrm{mL}$ in phosphate buffered saline (PBS; $1.5 \mathrm{mM} \mathrm{KH}_{2} \mathrm{PO}_{4}, 6.5 \mathrm{mM} \mathrm{Na}_{2} \mathrm{HPO}_{4}, 137 \mathrm{mM} \mathrm{NaCl}, 2.7 \mathrm{mM}$ $\mathrm{KCl} ; \mathrm{pH} 7.4$ ) and $20 \mu \mathrm{L}$ of this solution was added to each well. After incubation for $4 \mathrm{~h}$ at $37^{\circ} \mathrm{C}$ in a humidified incubator with $5 \%$ $\mathrm{CO}_{2}$, the medium/MTT mixtures were removed and the formazan crystals formed by the mitochondrial dehydrogenase activity of vital cells were dissolved in $100 \mu \mathrm{L}$ of DMSO per well. The absorbance of the wells was read with a microplate reader (BioRad Instruments) at $570 \mathrm{~nm}$. Effects of the drug cell viability were calculated using cell treated with DMSO as control.

Data Analysis: Cell survival was calculated using the formula: Survival (\%) = [(absorbance of treated cells - absorbance of culture medium)/ (absorbance of untreated cells - absorbance of culture medium)] $\times 100$ [24]. The experiments were done in triplicate and the inhibitory concentration (IC) values were calculated from a dose response curve. $\mathrm{IC}_{50}$ is the concentration in ' $\mu \mathrm{M}$ ' required 
for $50 \%$ inhibition of cell growth as compared to that of control. $\mathrm{IC}_{50}$ values were determined from the linear portion of the curve by calculating the concentration of agent that reduced absorbance in treated cells, compared to control cells by $50 \%$. Evaluation is based on mean values from three independent experiments, each comprising at least six micro-cultures per concentration level.

\section{Comet Assay (Single Cell Gel Electrophoresis)}

To assess the genotoxic effect of the new steroidal derivatives, comet assay [25] was performed in MCF7 cells. The MCF7 $\left(1 \times 10^{6}\right)$ cells were treated with 10,25 and $50 \mu \mathrm{g} / \mathrm{mL}$ of steroidal derivatives for $24 \mathrm{~h}$. The cells were then washed and $200 \mu \mathrm{L}$ of cell suspension in low melting agarose (LMA) was layered on to the labelled slides precoated with agarose $(1.5 \%)$. The slides were placed on ice for $10 \mathrm{~min}$. and submerged in lysis buffer $(2.5 \% \mathrm{NaCl}, 100 \mathrm{mM}$ EDTA, $10 \mathrm{mM}$ Tris, $10 \%$ DMSO and $1 \%$ Troton $\mathrm{X}-100$ ) at $4^{\circ} \mathrm{C}$ at $\mathrm{pH} 10$ for more than $1 \mathrm{~h}$. The slides were then equilibrated in alkaline buffer (30 mM NaOH, $1 \mathrm{mM}$ EDTA) at $4^{\circ} \mathrm{C}$ at $\mathrm{pH} 13$, electrophoresed at $0.86 \mathrm{~V} / \mathrm{cm}$ at $4^{\circ} \mathrm{C}$, neutralized, washed and dried. At the time of capturing the images, the slides were stained with ethidium bromide $(\mathrm{EtBr}, 150 \mu \mathrm{L} 1 \mathrm{X})$ and cover slips were placed over them. For visualization of DNA-damage, EtBr-stained slides were observed under 209 objectives of a fluorescent microscope (Olympus BX-51, Japan). The images of 50-100 randomly selected cells were captured per slide using a CCD camera.

\section{Result and Discussion}

\section{Chemistry}

Development of highly functional molecules from simple building blocks has always been the curiosity of synthetic chemists. So, we here in report the convenient route for the synthesis of new thiazolidinones [5-8] by reacting acetophenone and its derivatives [1-4] with hydrazine and merceptoacetic acid in absolute ethanol for the period of about $5 \mathrm{~h}$ under reflux conditions (Scheme 1 ) and on the completion of reaction, products were obtained in better yields (68-71\%). The tentative mechanism for the formation of thiazolidinones [5-8] has been proposed in scheme 2. The mechanism depicts clearly the formation of hydrazone in situ first by simple condensation which later undergo cyclization with merceptoacetic acid hence leads to the formation of the products [5-8]. The structures of these compounds were characterized by spectral (IR, ${ }^{1} \mathrm{H}$ NMR, ${ }^{13} \mathrm{C}$ NMR, MS) and analytical methods.
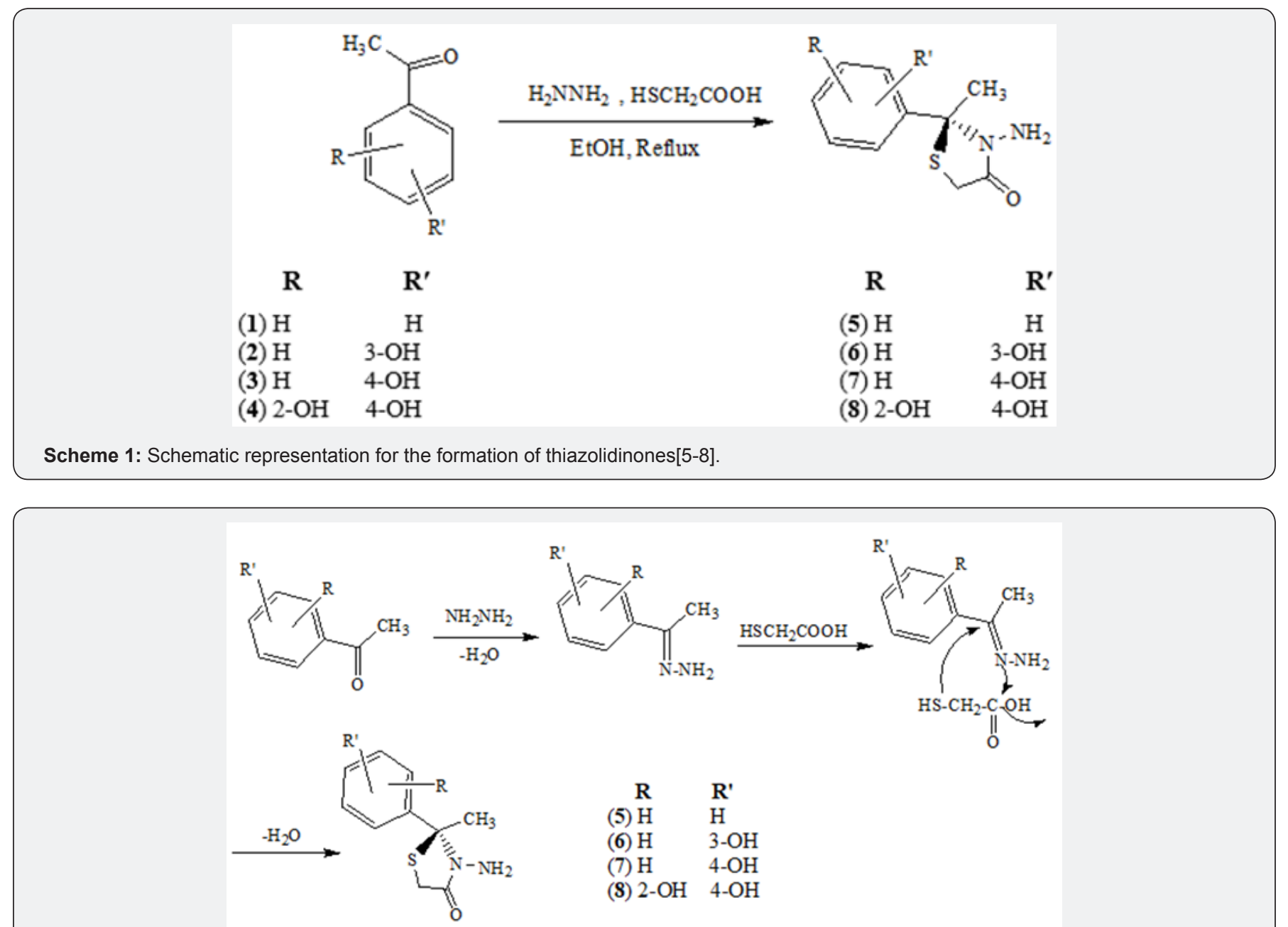

Scheme 2: Proposed mechanism of formation 3-amino-2-methyl-2-phenyl thiazolidin-4-one derivatives [5-8]. 


\section{Stereochemistry}

The stereoselectivity of these thiazolidinones can be explained by considering that there is a considerable amount of steric hindrance to ring-closure from one side of the ring at Carbonyl carbon which might be explained on the basis that the sulfur atom is bulkier than nitrogen during cyclization. Thus, the thiazolidinone ring closes at carbonyl carbon, by the attack of sulfur of mercaptoacetic acid moiety, preferentially from the front $(\beta$, axial) so that the nitrogen has an equatorial orientation $(\alpha$, equatorial) to avoid steric repulsion, giving minimum steric hindrance and maximum stability. This is further supported by the fact that during cyclization the nitrogen already attached to carbonyl carbon is moved towards the back ( $\alpha$, equatorial) side to reduce the steric hindrance, and leaving the front $(\beta$, axial) side for the attack of nucleophile to close the thiazolidinone ring. Therefore, the only product of this reaction with R stereochemistry was selectively obtained. The dreiding models also suggest the attack of sulfur from the $\beta$-side which pushes the nitrogen to the less hindered $\alpha$-side. Hence the formulation of the compound as $\mathrm{R}$ is preferred over its isomer $\mathrm{S}$.

The characterization studies showed good agreement with proposed structures of thiazolidinones [26], [5-8] (Scheme 1). In their IR spectra the presence of absorption bands in the range $3215-3236 \mathrm{~cm}^{-1}$ shows the presence of NH2 while as the absorption bands at $1645-1679,1620-1625$ and $3318-3358 \mathrm{~cm}^{-1}$ confirm the presence of $\mathrm{C}=\mathrm{O} \& \mathrm{CH}=\mathrm{CH}$ (arom.) and $\mathrm{OH}$ groups, respectively in the compounds [5-8]. The presence of bands at 1229-1234 and $647-680 \mathrm{~cm}^{-1}$ were ascribed to $\mathrm{C}-\mathrm{N}$ and C-S groups, respectively. In ${ }^{1} \mathrm{H}$ NMR study of the compounds [5-8], the three downfield singlets at $\delta 8.2-8.0,7.3-7.5,4.2$ were ascribed to $\mathrm{OH}, \mathrm{NH}_{2}$ and $\mathrm{CH}_{3}$ while as the presence of broad multiplet at $\delta$ 6.1-6.9 revealed the presence of aromatic protons. The presence of two proton singlet at $\delta 3.36$ 3.44 was ascribed to two methylene protons in ${ }^{13} \mathrm{C}$ NMR study, the signals at $\delta 172-176,121-131,47-50$ and 38-44 confirm the presence of $\mathrm{C}=\mathrm{O}, \mathrm{C}=\mathrm{C}$ (arom.), $\mathrm{C}-\mathrm{N}$ and $\mathrm{CH} 2$ groups respectively in the products [5-8]. Finally, the presence of distinct molecular ion peak [M+.] at m/z: 208, 224, 224 and 240 in the MS after following the nitrogen rule, also proved the formation of compounds [58]. The strategy can also be applied to diverse ketones, in that way thiazolidinones may also allow further modifications on the substituted heterocyclic systems $[27,28]$.

\section{Anticancer Activity}

The cytotoxicity of thiazolidinones 5-8 (341-344) was studied by MTT assay [23]. The data reported in Table 1 suggest that compound 5-8 (341-344) showed different levels of cytotoxicity. During the screening, the potential behaviour was depicted by the compounds against given cancer cells. The compound 6 showed $\mathrm{IC}_{50}=9.63 \mu \mathrm{mol} \mathrm{L}^{-1}$ (HT-29), 9.73 $\mu \mathrm{mol} \mathrm{L}-1$ (MCF7), $11.45 \mu \mathrm{mol} \mathrm{L}{ }^{-1}$ (A549). Compound 7 also depicted minimum $\mathrm{IC}_{50}$ value in the range of $12.79 \mu \mathrm{mol} \mathrm{L-1}$ (HT-29) and $10.60 \mu \mathrm{mol} \mathrm{L}^{-1}$ (MCF7) while compound 5 showed minimum IC50 $=9.11 \mu \mathrm{mol} \mathrm{L}^{-1}$ (A545) and $15.26 \mu \mathrm{mol} \mathrm{L}^{-1}$ (HepG2) cell line. From the Table 1 it is clear that the $\mathrm{IC}_{50}$ for compound 6 against A549 and HeLa cells was found to be 11.45 and $11.72 \mu \mathrm{M} \mathrm{L}^{-1}$ which is close to the $\mathrm{IC}_{50}$ of Cisplatin 12.0 and $9.43 \mu \mathrm{M} \mathrm{L}^{-1}$, respectively against the same cells. IC50 for compound 6 against HeLa cell line was found to be $11.72 \mu \mathrm{M} \mathrm{L}^{-1}$ which were also close to the $\mathrm{IC}_{50}$ of Cisplatin 9.43 against the same cell line.55 Similarly $\mathrm{IC}_{50}$ for compounds 5 and 6 against HepG2 was found to be 11.26 and $13.56 \mu \mathrm{M} \mathrm{L}^{-1}$ which is also near to $\mathrm{IC}_{50}$ of Cisplatin9.8 against same cell line. It can be concluded that compound 6 and 7 showed potential in vitro cytotoxicity against A549, HeLa, HepG2 and A545 cell lines by depicting IC C $_{50}$ close to that of Cisplatin, thus can be considered as potential cytotoxic agents. Compound 5-8 also showed marked cytotoxicity against HL-60 and HepG2 cell lines by showing $\mathrm{IC}_{50}$ less than standard drug, 5-fluorouracil.

Table 1: The $\mathrm{IC}_{50}$ of compounds [5-8] against cancer cells.5-FU = 5-Fluorouracil.

\begin{tabular}{|c|c|c|c|c|c|c|c|c|}
\hline \multicolumn{9}{|c|}{ IC $_{\mathbf{5 0}}\left(\boldsymbol{\mu} \mathbf{M L}^{-1}\right)$} \\
\hline Comp. & Lung A545 & Breast MCF7 & Cervical HeLa & Leukaemia HL-60 & Colon SW480 & Hepatic HepG2 & Colon HT-29 & Lung A549 \\
\hline 5 & 9.11 & 27.39 & 15.13 & $>50$ & 26.11 & 15.26 & 17.12 & 16.31 \\
\hline 6 & 13.45 & 9.73 & 11.72 & 20.17 & 12.81 & 11.01 & 9.63 & 11.45 \\
\hline 7 & 16.53 & 10.60 & 17.37 & 28.34 & $>50$ & 24.37 & 12.79 & 20.64 \\
\hline 8 & 17.24 & 21.33 & 14.22 & $>50$ & $>50$ & 13.56 & 14.87 & 22.31 \\
\hline Cisplatin & 8.9 & 9.3 & 9.43 & 7.83 & 3.52 & 9.80 & 7.24 & 12.0 \\
\hline 5-FU & 15.4 & 15.3 & 16.32 & $>50$ & 15.17 & $>50$ & 9.79 & 12.8 \\
\hline
\end{tabular}

\section{Comet Assay}

To understand the apoptotic degradation of DNA, the compound 5-8 were screened against MCF7 in comet assay. There was dose-dependent increase in the tail length when cells were treated with compound 5-8. Compound 6 presented maximum apoptotic DNA damage among the three thiazolidinone studied, which is in accordance with its maximum cytotoxicity as seen in
MTT assay. The quantified increase in DNA damage suggested that the thiazolidinone derivative 6 induced dose-dependent fragmentation of chromosomal DNA leading to apoptosis. The images of comet assay for control, cells treated with compound $5-8(50 \mu \mathrm{g} / \mathrm{mL})$ are depicted in Figure 1. Slides were analysed for parameter like tail length (TL), using image analyzer CASP software version 1.2.2. The results of the assay for tail length are shown in Figure 2. 


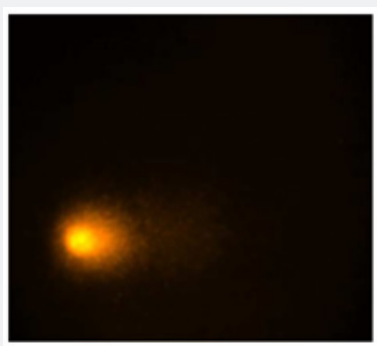

$5(50 \mu \mathrm{g} / \mathrm{mL})$

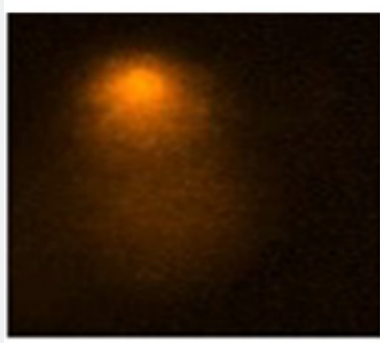

$8(50 \mu \mathrm{g} / \mathrm{mL})$

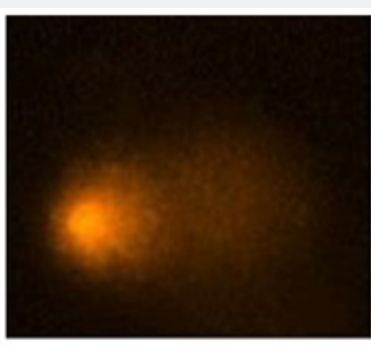

$6(50 \mu \mathrm{g} / \mathrm{mL})$

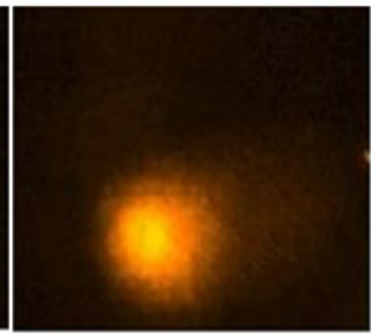

$7(50 \mu \mathrm{g} / \mathrm{mL})$

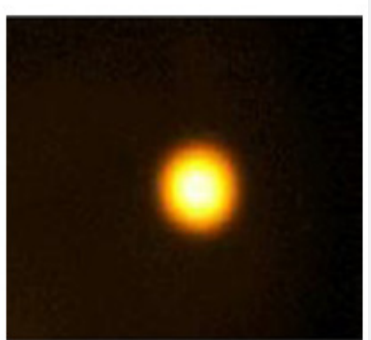

Control (Untreated)

Figure 1: Detection of DNA damage in MCF7 cells. Treated cells (24h) were layered over agarose gel, lysed, electrophoresed in alkaline buffer and stained with propidium iodide.

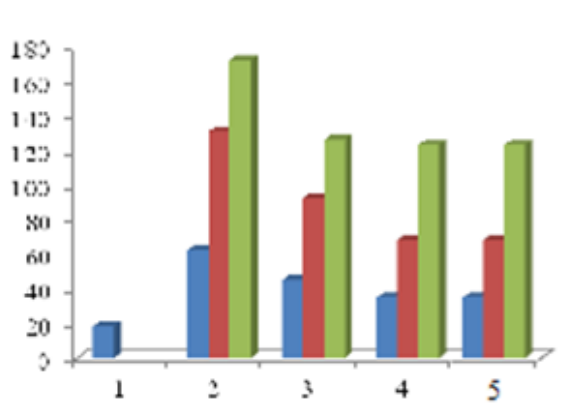

$$
\begin{gathered}
1=\text { Control (untreated) } \\
2=\text { Blue }(10 \mu \mathrm{g} / \mathrm{mL}) \text {, red }(25 \mu \mathrm{g} / \mathrm{mL}), \\
\text { Green }(50 \mu \mathrm{g} / \mathrm{mL}) 5 \\
3=\text { Blue }(10 \mu \mathrm{gL}), \text { red }(25 \mu \mathrm{g} / \mathrm{mL}), \\
\text { Green }(50 \mu \mathrm{g} / \mathrm{mL}) 6 \\
4=\text { Blue }(10 \mu \mathrm{g} / \mathrm{mL}), \text { red }(25 \mu \mathrm{g} / \mathrm{mL}), \\
\text { Green }(50 \mu \mathrm{g} / \mathrm{mL}) 7 \\
5=\begin{array}{c}
\text { Blue }(10 \mu \mathrm{g} / \mathrm{mL}), \text { red }(25 \mu \mathrm{g} / \mathrm{mL}), \\
\text { Green }(50 \mu \mathrm{g} / \mathrm{mL}) 8
\end{array}
\end{gathered}
$$

Figure 2: Comparing the effect of thiazolidinones (5-8) on the tail length in comet assay.

\section{Conclusion}

The operationally simple reaction for convenient synthesis of thiazolidinones was successfully developed. The reaction got completed in almost $5 \mathrm{~h}$ and on completion; potential yields were obtained. This strategy offered a very straight forward, onepot and efficient method for access to new thiazolidinones. The compounds successfully revealed the cytotoxic and genotoxic behaviour against the different cancer cell lines. In conclusion, the present study showed that this one pot synthesized compounds can be used as a template for future development through modification and derivatization to design more potent and selective anticancer agents.

\section{Acknowledgement}

The authors thank Head of Chemistry Department OPJS University for successful completion of the work.

\section{References}

1. Kees KL Fitzgerald, JJJ Steiner, KE Mattes, JFMihan, et al. (1996) New potent antihyperglycemic agents in $\mathrm{db} / \mathrm{db}$ mice: synthesisand structure-activity relationship studies of (4-substituted benzyl) (trifluoromethyl)pyrazoles and-pyrazolones. J Med Chem 39: 39203928.

2. Shamsuzzaman, Aslam M, Salim A (1998) Stereoselective Synthesis of Steroidal (6R)-Spiro-1', 3', 4'-Thiadiazolines. J Chem Res pp. 824-827.

3. Himly M, Jahn-Schmid B,Pittertschatscher K, Bohle B,Grubmayr $\mathrm{K}$,et al. (2003) IgE-mediated immediate-type hypersensitivity to thepyrazolone drug propyphenazone. J. Allergy Clin Immunol 111(4): 882-886.

4. Watanabe T, Yuki S,Egawa M, Nishi H (1994) Protective effects of MCI-186 oncerebral ischemia: possible involvement of free radical scavenging and antioxidantactions. J Pharmacol Exp Ther 268(3): 1597-1601.

5. Singh H Kapoor, VK Paul D (1979) Heterosteroids and drug research. In: Progress in Medicinal Chemistry, Ellis GP, West GB. Eds, Springer: Amsterdam,Netherlands, p. 35. 
6. Chirag KP Rami, CS Panigrahi, B Patel CN (2010) Synthesis and biological evaluation of (4-substituted benzylidene)-3- methyl-1(substituted phenyl sulfonyl and substituted benzoyl)-1Hpyrazol5(4H)-one as anti-inflammatory agent. J Chem Pharm Res 2(1): 73-77.

7. Michon V, Penhoat CHD Tombret, F Gillardin JM Lepagez, et al. (1995) Preparation, structural analysis and anticonvulsant activity of 3- and 5-aminopyrazole N-benzoyl derivatives. Eur J Med Chem 30(2): 147152.

8. Janus SL Magdif AZErik, BP Claus N (1999) Synthesis of triazenopyrazole derivatives as potential inhibitors of HIV-1. Monatsh fur Chem 130(9): 1167-1171.

9. Wu TW, Zeng LH, Wu J, FungKP (2002) Myocardial protection of MCI186 inrabbit ischemia-reperfusion. Life Sci 71(19): 2249-2252.

10. Al-Haiza MA, El-Assiery SA, Sayed GH (2001) Synthesis \& potential antimicrobialactivity of new compounds containing the pyrazol-3-one moiety. Acta Pharm 51(4): 251-256.

11. Castagnolo D,Manetti F,Radi M,Bechi B, Pagano M,et al. (2009) Bioorg Med Chem 17: 5716-5721.

12. Stanovnik B,Svete J (2002) Houben-Weyl Methods of Molecular Transformations.Sci Synth 12: 220-223.

13. Tong A,Akama Y, Tanaka S (1989) Reversed-phase high-performance liquidchromatography of aluminium(III) and indium(III) with 1-phenyl-3-methyl-4-benzoyl-5-pyrazolone J Chrom 478: 408-412.

14. Samelson H,Lempicki A (1963) Fluorescence and Lifetimes of Eu ChelatesJ Chem Phys 39: 110-115.

15. Visvanathan K, Davidson NE (2003) Aromatase inhibitors as adjuvant therapy inbreast cancer. Oncology 17(3): 335-339.

16. Li X, Singh SM, Cote J,Laplante S, Veilleux R (1995) Synthesis and in vitroevaluation of 4-substituted $\mathrm{N}$-(1,1-dimethylethyl)-3-oxo4 -androstene-17 $\beta$-carboxamides as $5 \alpha$-reductase inhibitors and antiandrogens.J Med Chem 38: 1456-1461.
17. DiasRS,Lindman B (2008) DNA Interactions with Polymers and Surfactants,Wileyand Sons, New Jersey, USA, p. 2.

18. Girod JC,Johson WCJ, Huntington SK,Maestre MF (1983) Conformation ofdeoxyribonucleic acid in alcohol solutions. Biochemistry 12(25): 5092-5096.

19. Meng X, Liu L, Zhou C Wang L, Liu C (2008) Dinuclear Copper(II) Complexes of a Polybenzimidazole Ligand: Their Structures and Inductive Roles in DNA Condensation.Inorg Chem 47: 6572-6574.

20. Wilson RW, Bloomfield VA (1979) Counterion-induced condensation ofdeoxyribonucleic acid. a light-scattering study. Biochemistry 18(11): 2192-2196.

21. Cohen P Kidson C (1968) Conformational analysis of DNA-poly-l-lysine complexesby optical rotatory dispersion. J Mol Biol 35(1): 241-245.

22. Dar AM, Nabi R, Mir S,Gatoo MA,Shamsuzzaman Lone SH (2018) Synthesisof steroidal imidazolidinthiones as potential apoptotic agents: Investigation by theoreticaland experimental studies. Bioorganic Chemistry 79: 190-200.

23. Dar AM, Mir S, Jan M,Shamsuzzaman (2017) Spectroscopic studies of newlysynthesized steroidal dihydropyrroles.Eur Chem Bull 6(7): 321324.

24. Dar AM, Rah B, Mir S, Nabi R,ShamsuzzamanGatoo MA,et al. (2018) DNA binding, artificial nuclease activity and cytotoxic studies of newly synthesizedsteroidal pyrimidines. International Journal of Biological Macromolecules 111: 52-61.

25. Mosmann T (1983) Rapid colorimetric assay for cellular growth and survival:applicationto proliferation and cytotoxicity assays. J Immunol Methods 65(1-2): 55-63.

26. Saxena HO,Faridi U, Kumar JK,Luqman S, Darokar MP, et al. (2007) Synthesis of chalcone derivatives on steroidal frameworkand their anticancer activities. Steroids 72(13): 892-900.

27. Singh NP (2000) Microgels for estimation of DNA-strand breaks, DNA protein crosslinksand apoptosis. Mutat Res 455(1-2): 111-127.

\section{Your next submission with Juniper Publishers will reach you the below assets}

- Quality Editorial service

- Swift Peer Review

- Reprints availability

- E-prints Service

- Manuscript Podcast for convenient understanding

- Global attainment for your research

- Manuscript accessibility in different formats

( Pdf, E-pub, Full Text, Audio)

- Unceasing customer service

Track the below URL for one-step submission https://juniperpublishers.com/online-submission.php 